Riga, Latvia, November 20, 2020

\title{
PRODUCTIVITY OF SUNFLOWER HYBRIDS DEPENDING ON ELEMENTS OF TECHNOLOGY OF CULTIVATION IN THE CONDITIONS OF THE RIGHT-BANK STEPPE OF UKRAINE
}

\author{
Hennadii Pinkovskyi ${ }^{1}$ \\ Semen Tanchyk ${ }^{2}$
}

DOI: https://doi.org/10.30525/978-9934-26-002-5-48

Sunflower (Helianthus annuus) is the most important oil crop in Ukraine and Europe.

The ability to form high level of productivity of sunflower plants significantly depends on their ability to adapt to growing conditions that are not stable.

Among natural factors holding back growth of sunflower production by increasing yields in steppe, is the lack of moisture in plants due to the arid climate [1, p. 128].

The use of moisture by sowing sunflowers can be regulated by sowing dates to some extent. Shifting sowing dates to earlier ones makes it possible to change the conditions of growth and development of sunflower plants, namely, the plants are better provided with moisture, and it is possible to avoid critical temperature periods of plant development [2, p. 51, 127].

To increase the productivity of sunflower plants is the search for optimal sowing dates that fall on different calendar dates.

Analysis of literature sources shows the presence of opposing views on determining the timing of sowing sunflower. Some argue that the optimal time for sowing sunflower is the period when the soil temperature at a depth of 10 $\mathrm{cm}$ is $+8-10^{\circ} \mathrm{C}$, at which sunflower plants have formed the highest performance elements and provided the highest yield without additional costs [3, p. 19; 4, p. 56; 5, p. 175]. At the same time, the results of research by other scientists prove that the optimal time for sowing sunflower is the period when the average daily stable soil temperature at a depth of $10 \mathrm{~cm}$ reaches $10-12^{\circ} \mathrm{C}$. During this sowing period, pre-sowing cultivation can destroy the bulk of early annual weed seedlings, sow sunflower seeds in well-heated, weed-free soil and get friendly seedlings - on the 9th-12th day after sowing [6, p. 229; 7, p. 124].

Also, according to some authors, sunflower is a crop of early sowing, sunflower seeds can germinate at a temperature of $4-5^{\circ} \mathrm{C}$, and seedlings can

\footnotetext{
${ }^{1}$ National University of Bioresources and Nature Management of Ukraine, Ukraine

${ }^{2}$ National University of Bioresources and Nature Management of Ukraine, Ukraine
} 
withstand short-term spring frosts - up to minus $4-6^{\circ}$ C. [8, p. 62; 9, p. 21; 10, p. 367]. Early sowing, when the soil warms up to $6-8^{\circ} \mathrm{C}$ allows to shift the time of technological maturity in sunflower hybrids to the first or second decade of September, that is to avoid the rainy season during harvest [11, p. 184 12, p. 163].

However, it is not recommended to sow sunflower at a later date when the seed layer is dried and sunflower seeds do not germinate for a long time. In addition, due to the shift of growing season, ripening of crop falls on the cool period. In this regard, the vegetation of plants is prolonged, seed yield, oil and protein content are reduced [13, p. 20].

Plant density depends on both climatic conditions and the genotype of the hybrid and in steppe of Ukraine ranges from 40 to 70 thousand plants per hectare [14, p. 16].

The aim of research is to increase productivity by optimizing the time of sowing and density of standing sunflower plants in the Right Bank Steppe of Ukraine.

The field experiment was conducted in the experimental field of IAS NAAS Kirovohrad region. The main difference between the soil cover is ordinary heavy loam chernozem. The content of humus in the arable soil layer is $4.72 \%$, easily hydrolyzed nitrogen $-104 \mathrm{mg} \mathrm{kg}^{-1}$ of soil, mobile phosphorus - $191 \mathrm{mg} \mathrm{kg}^{-1}$ of soil and exchangeable potassium - $142 \mathrm{mg} \mathrm{kg}^{-1}$ of soil, $\mathrm{pH}_{\mathrm{KCL}}-5.8$.

Field experiments were established by the method of split plots. In threefactor experiment studied sunflower hybrids - Forward, LG 56.32, LG 54.85, LG 5582 (Factor A); Terms of sowing - the first when warming up the soil at a depth of seed wrapping to $5-6^{\circ} \mathrm{C}$, the second when warming the soil at a depth of seed wrapping to $7-8^{\circ} \mathrm{C}$, the third when warming the soil at a depth of seed wrapping to $9-10^{\circ} \mathrm{C}$ (Factor B); Density of standing plants-50, 60, 70 thousand ha (Factor $\mathrm{C}$ ). The experiment was repeated three times. The area of sowing plot is $50.4 \mathrm{~m}^{2}$, the accounting area is $25.2 \mathrm{~m}^{2}$. The technology of growing sunflower in the experiment is generally acceptable, except for the factors baing studied. The predecessor is spring barley.

The weather conditions of the 2016-2018 research differed from the longterm averages in terms of precipitation and temperature.

The content of available moisture in soil was determined by thermostaticweight method.

Statistical analysis of research results was performed by multifactor variance method, calculations were performed using 'MS Excel Agcstat'.

Research established significant dependence of yield of sunflower hybrids on the density of plants, weather conditions, biological features of hybrids and sowing time (Table 1 ). 
Table 1

Yield of sunflower hybrids, depending on the sowing time and plant density, $\mathrm{t} \mathrm{ha}^{-1}$ (average for 2016-2018)

\begin{tabular}{|c|c|c|c|c|c|c|c|c|c|c|}
\hline \multirow{3}{*}{ Hybrid } & \multirow{3}{*}{ Year } & \multicolumn{3}{|c|}{$\begin{array}{c}\text { Soil temperature } \\
5-6^{\circ} \mathrm{C} \\
\end{array}$} & \multicolumn{3}{|c|}{$\begin{array}{c}\text { Soil temperature } \\
7-8{ }^{\circ} \mathrm{C} \\
\end{array}$} & \multicolumn{3}{|c|}{$\begin{array}{c}\text { Soil temperature } \\
9-10{ }^{\circ} \mathrm{C} \\
\end{array}$} \\
\hline & & \multicolumn{9}{|c|}{$\begin{array}{c}\text { Plant density, thousand pieces ha } \\
\end{array}$} \\
\hline & & 50 & 60 & 70 & 50 & 60 & 70 & 50 & 60 & 70 \\
\hline \multirow{4}{*}{$\begin{array}{l}\text { Forward } \\
\text { (control, } \\
\text { standard) }\end{array}$} & 2016 & 2,70 & 2,62 & 2,65 & 2,87 & 2,74 & 2,41 & 2,79 & 2,73 & 2,70 \\
\hline & 2017 & 3,02 & 2,91 & 2,66 & 3,27 & 3,29 & 2,79 & 3,21 & 3,37 & 3,27 \\
\hline & 2018 & 3,12 & 3,29 & 2,99 & 2,82 & 2,93 & 3,06 & 2,87 & 3,17 & 2,81 \\
\hline & average & 2,94 & 2,94 & 2,76 & 2,98 & 2,98 & 2,75 & 2,95 & 3,09 & 2,92 \\
\hline \multirow{4}{*}{$\begin{array}{l}\text { LG } \\
56.32\end{array}$} & 2016 & 2,79 & 2,75 & 2,68 & 3,06 & 3,62 & 3,29 & 3,24 & 3,41 & 3,35 \\
\hline & 2017 & 3,11 & 3,42 & 3,56 & 3,19 & 3,47 & 3,23 & 3,30 & 3,55 & 3,7 \\
\hline & 2018 & 3,46 & 3,76 & 3,46 & 3,28 & 3,51 & 3,33 & 3,53 & 3,90 & 3,30 \\
\hline & average & 3,12 & 3,30 & 3,23 & 3,17 & 3,5 & 3,28 & 3,35 & 3,62 & 3,45 \\
\hline \multirow{4}{*}{$\begin{array}{l}\text { LG } \\
54.85\end{array}$} & 2016 & 3,26 & 3,50 & 3,00 & 3,33 & 3,33 & 3,18 & 3,23 & 3,12 & 2,93 \\
\hline & 2017 & 3,49 & 3,69 & 3,62 & 3,7 & 3,99 & 3,52 & 3,98 & 4,10 & 3,58 \\
\hline & 2018 & 3,53 & 3,74 & 3,41 & 3,37 & 3,24 & 3,27 & 3,58 & 3,63 & 3,15 \\
\hline & average & 3,42 & 3,64 & 3,34 & 3,46 & 3,51 & 3,32 & 3,59 & 3,61 & 3,22 \\
\hline \multirow{4}{*}{$\begin{array}{l}\text { LG } \\
55.82\end{array}$} & 2016 & 3,22 & 3,27 & 2,70 & 3,26 & 3,21 & 3,38 & 3,28 & 2,96 & 3,38 \\
\hline & 2017 & 3,95 & 4,04 & 3,74 & 3,91 & 4,16 & 3,54 & 3,69 & 3,98 & 3,59 \\
\hline & 2018 & 3,74 & 4,24 & 3,58 & 3,47 & 3,83 & 3,84 & 3,86 & 3,99 & 3,79 \\
\hline & average & 3,63 & 3,85 & 3,33 & 3,54 & 3,73 & 3,58 & 3,60 & 3,64 & 3,58 \\
\hline $\begin{array}{l}\text { NIR } \\
05 \text {, t ha } \\
\text { for }\end{array}$ & \multicolumn{10}{|c|}{$\begin{array}{l}\text { factors A } 0,13 \\
\text { factors B } 0,11 \\
\text { factors C } 0,11 \\
\text { total ABC } 0,40\end{array}$} \\
\hline
\end{tabular}

In general, over the three years of research, the highest yields of the hybrids LG 5582, LG 54.85, LG 56.32, Forward was obtained at a density of 60 thousand plants ha. In the first sowing period, the highest seed yield of $3.85 \mathrm{t} \mathrm{ha}^{-1}$ was provided by the LG 55.82 hybrid, which was $5.5 \%$ more than in the third term and $3.2 \%$ in the second sowing period. The plants of the LG 54.85 hybrid formed a seed yield of $3.64 \mathrm{t} \mathrm{ha}^{-1}$ for sowing in the first term, which is $0.9 \%$ more for the third term and $3.6 \%$ for the second sowing period. For the sowing in the third term, the highest seed yields were formed by hybrids of Forward and LG 56.32 - 3.09 and $3.62 \mathrm{t} \mathrm{ha}^{-1}$, which is higher by 3.6 and $3.4 \%$ for the second term, 4.9 and $8.9 \%$, respectively first term. Hybrids of sunflower LG 56.32, LG 54.85 and LG 55.82 by seed yield significantly exceeded the control variant. Thus, the LG 55.82 sunflower hybrid exceeded the Forward hybrid yield by $0.91 \mathrm{t} \mathrm{ha}^{-1}$, or $23.7 \%$; LG 54.85 at $0.7 \mathrm{t} \mathrm{ha}^{-1}$, or $19.3 \%$; LG 56.32 - up $0.53 \mathrm{t} \mathrm{ha}^{-1}$, or $14.7 \%$. 
In the context of climate change and the emergence of new hybrids in the production of research to optimize the timing of sowing and density of standing plants of different hybrids is relevant and important for science and production.

\section{References:}

1. Yeremenko, O. A. (2017). Produktyvnist hibrydiv soniashnyku (Helianthus annuus L.) u Pivdennomu Stepu [Productivity of sunflower hybrids (Helianthus annuus L.) in the Southern Steppe]. Zbirnyk naukovykh prats Natsionalnoho naukovoho tsentru «Instytut zemlerobstva NAAN», vol. 1, pp. 127-139. URL: http://nbuv.gov.ua/UJRN/znpzeml_2017_1_14

2. Pinkovskyi, H. V., Tanchyk, S. P. (2019). Produktyvnist ta vodospozhyvannia serednorannikh hibrydiv soniashnyka zalezhno vid strokiv sivby y hustoty stoiannia roslyn u Pravoberezhnomu Stepu Ukrainy [Productivity and water consumption of mid-early sunflower hybrids depending on the sowing time and plant standing density in the Right-Bank Steppe of Ukraine]. Zroshuvane zemlerobstvo: mizhvidomchyi tematychnyi naukovyi zbirnyk. Kherson: OLDI-PLIuS, vyp. 72, pp. 47-52. DOI: https://doi.org/10.32848/0135-2369.2019.72.11

3. Kovalenko, O. O. (2005). Produktyvnist hibrydiv sonyashnyku zalezhno vid strokiv sivby ta hustoty stoyannya roslyn u pivnichniy pidzoni Stepu Ukrayiny [Productivity of sunflower hybrids depending on sowing time and plant standing density in the Northern Sub-steppe of Ukraine]. Avtoref. dys. na zdobuttya nauk. stupenya kand. s.-h. nauk. Dnipropetrovsk.

4. Kocherha, A. A., Butiaha, Ya. V. (2015). Vplyv strokiv sivby na urozhainist soniashnyku [Influence of sowing time on sunflower yield]. Materialy III naukovopraktychnoi internet-konferentsii «Innovatsiini aspekty tekhnolohii vyroshchuvannia, zberihannia i pererobky produktsii roslynnytstva». Poltavska derzhavna ahrarna akademiia.

5. Markova, N. V. (2011). Formuvannia produktyvnosti hibrydiv soniashnyku zalezhno vid strokiv sivby ta zakhodiv borotby z burianamy v umovakh Pivdennoho Stepu Ukrainy [Formation of productivity of sunflower hybrids depending on terms of sowing and measures of control of weeds in the conditions of the Southern Steppe of Ukraine]. Bulletin of Agricultural Science, vol. 4(61), pp. 170-175.

6. Mynkovskyy, A. E., Polyakov, A. Y. (2007). Produktyvnost' hybryda Zaporozhskyy $28 \mathrm{v}$ zavysymosty ot strokov seva y hustoty stoyanyya rastenyy [The productivity of Zaporizhzhya 28 hybrid, depending on terms of sowing and plant standing density]. Naukovo-tekhnichnyi byuleten Instytutu oliinykh kultur NAAN, vol. 12, pp. 225-229.

7. Totskyi, V. M. (2009). Vplyv strokiv sivby na formuvannia elementiv produktyvnosti ta vrozhainosti soniashnyku [Influence of sowing dates on the formation of elements of productivity and yield of sunflower]. Visn. Poltavskoi derzh. ahrar. Akademii, vol. 1, pp. 122-124.

8. Andriienko, O., Zhuzha, O., Andriienko, A. (2016). Prychyny nevypovnenosti nasinnia ta koshyka soniashnyku [Causes of incomplete seeds and baskets of sunflower]. Propozytsiia, vol. 3, pp. 60-68. 
9. Pleshakov, N. A. (1987). Vlyianye srokov poseva na prorastanye semian y urozhai podsolnechnyka [Impact of planting dates on seed germination and sunflower harvest]. Biul. nauch.-tekh. ynform. po maslychnym kulturam. Krasnodar, vol. 1, pp. 21-24.

10. Pustovoit, V. S. (1990). Yzbrannye Trudy [Selected Works]. Moscow: Ahropromyzdat, 367 p.

11. Andriienko, A. L. (2013). Yak virno vybraty strok sivby soniashnyku? [How to choose the right time of sunflower sowing?]. Ahronom, vol. 1, pp. 178-184.

12. Trotsenko, V. I., Butenko, A. O. (2002) Osoblyvosti nasinnytstva sortiv soniashnyku v Lisostepovii zoni Ukrainy [Peculiarities of sunflower seed production in the Forest-Steppe zone of Ukraine]. Nauchnye trudy Krymskoho HAU. Symferopol, vol. 72, pp. 163-166.

13. Sydorenko, Yu. Ya., Turchyn, V. V., Vasylenko, Y. A., Kharchenko, N. L. (1990). Po yntensyvnoy tekhnolohy [By intensive technology]. Tekhnycheskye kul'tury, vol. 2, p. 20.

14. Oleksiuk, O. M. (2000). Vplyv sposobiv sivby i hustoty stoiannia roslyn na urozhainist hibrydiv soniashnyka v Pivnichnii chastyni Stepu Ukrainy [Influence of sowing methods and plant density on yield of sunflower hybrids in the Northern part of the Steppe of Ukraine]. Avtoref. dys. na zdobuttya nauk. stupenya kand. s.-h. nauk. Dnipropetrovsk, $16 \mathrm{p}$.

\section{POSITIVE EFFECT OF DEFERMENT SEEDING CAMPAIGN FOR WINTER WHEAT DUE TO FALL DROUGHT IN EAST OF UKRAINE}

\section{Tetiana Tretiakova ${ }^{1}$}

DOI: https://doi.org/10.30525/978-9934-26-002-5-49

Introduction. The Steppe of East Ukraine is a specific drought region which has strong wind and high summer temperature. Last ten years rainfall is declining. That is why agricultural companies change management, timing and use moisture saving technology. They are facing new obstacles such as absent rainfall in September (ten years ago normal was 28-35 mm of rainfall during September), 0\% moisture in one-meter soil.

Seeding terms for winter wheat, considering the characteristics of the region:

- Early sowing 25.08-05.09 is used on areas that were cultivated but not sown in a calendar year, there is no predecessor, due to which moisture can be retained on them

\footnotetext{
${ }^{1}$ State Institution «Luhansk Taras Shevchenko National University», Ukraine
} 